\title{
Urgency of Local-Owned Enterprises (BUMD) Law as Good Corporate Governance Basis in Indonesia
}

\author{
Darwin Nasution \\ $\mathrm{PhD}$ in Law Program, Graduate School \\ Universityof Sumatera Utara \\ Medan, Indonesia \\ darwinst_sh@yahoo.com
}

\author{
Ningrum Natasya Sirait \\ PhD in Law Program, Graduate School \\ Universityof Sumatera Utara \\ Medan, Indonesia \\ ningrum.sirait@gmail.com
}

\begin{abstract}
Indonesian Law Number 23 on Local Government provides an authority to the local goverment to establish a LocalOwned Enterprise which is well known as BUMD (Badan Usaha Milik Daerah). BUMD has strategic roles in the autonomy era for providing benefitfor the economic growth, conducting general benefit and raising profit. However, it is difficult to achieve the goals of BUMD since the absence of laws on BUMD.
\end{abstract}

There are two impacts of the absence of the law namely the ambiguity of managing BUMD both promoting public profit and achieving the breach of good corporate governance principle.

This study uses stakeholder theory of modern corporation as the grand theory, fiduciary theory of corporation as middle range theory and legislation theory as applied theory.

The result shows that firstly, Indonesia needs to have a special regulation concerning BUMD. Nowadays, although there are some regulations mentioning about BUMD both in national and local levels, it does not specifically discuss BUMD. Secondly, it is a must to have a fitted management in order to achieve the Goal of Establishment of BUMD either using stakeholder or stakeholder prinsciples.

Keywords- local-owned enterprises (BUMD); government regulation; Indonesian laws

\section{INTRODUCTION}

One of the objectives of the Republic of Indonesia as stated in the Preamble of the 1945 Constitution (the 1945 Constitution) is to promote public welfare. Efforts to promote the public welfare must be done as planned, programmed, systematic and sustainable activities in order to improve the welfare and the quality of life of all community. [1] To implement the public welfare through a people-centered economy, Friedman states that the state shall have the following four roles; first, aprovider of the public welfare,throughwhom the state guarantees the minimum standard of life of its citizens in the form of social security such as national social security system; second, a regulator, by whom the state uses its power to make regulations or policies for the public welfare such as Law Number 24 of 2011 on Social Security Board (known as BPJS) and Law Number 17 of 2012 on Cooperatives; third, an entrepreneur, through whom the state conducts economic enterprises in a certain sector through state-owned corporations accompanied by private sectors; and fourth, an umpire (controller), through whom the state formulates or assesses the fair standards in economic activities so that the economic activities can proceed fairly. [2]

The efforts to promote public welfare through the role of entrepreneurs are undertaken by the Central Government together with the Local Government through the concept of regional autonomy under Law Number 32 of 2004 on Regional Government which is then amended by Law Number 23 of 2014 on Regional Government (Law onLocal Government). Under this Law, local governments have an opportunity to manage, develop, and build their own regions in accordance with the needs and potentials of each region.

These efforts can be realized in two ways, first, the establishment of State-Owned Enterprises (hereinafter called BUMN) by the Central Government; second; the establishment of Local-Owned Enterprises (hereinafter called BUMD) by the Regional Government both at the provincial level and regional level. The purpose of the establishment of BUMN and BUMD is motivated by the same principles, [3] some of which include providing benefits for economic development in general by implementing public benefits and earning profits based on a good corporate governance.

The purpose of the establishment of BUMN and BUMD is similar, but the regulation underlying BUMN and BUMD is different.BUMN has been specifically regulated by Law Number 19 of 2003 on State-Owned Enterprises (hereinafter referred to as Law on BUMN). The Law on BUMN is a legal basis of BUMN management. If the BUMN management is related to other regulations, it can use such principles of regulation as lex superior derogat legi inferior(higher lawset aside lower law), lex specialis derogat legi generalis (special law set aside general law), and lex posterior derogat legi priori (recent law set aside old law); consequently, harmonization of regulation on BUMN management can be implemented.

Unlike BUMN, BUMD does not have any specific laws as the basis for its management. The regulation on BUMD through Law Number 5 of 1962 on Local Enterprises has been revoked by Law Number 6 of 1969 on Declaration to Invalidate Various Laws and Government Regulation in Lieu of Law. Elucidation of Article 2 of Law Number 5 of 1962 
states "The Law in Attachment III contains materials and issues that need to be accommodated in a new law. Due to the timing of the settlement of the law as well as to avoid a legal void, the declaration to invalidate the law is stipulated when the law replacing it comes into force". No replacement law has ever been enacted until now; therefore, the provisions regarding Local Enterprises continues to refer to Law Number 5 of 1962 on Local Enterprises. Judging from the year of its issuance, the legal substance contained in the law certainly does not correspond to the current conditions. Prabowo Soenirman, the Chairman of the BUMD Association of Indonesia, explained that Law Number 5 of 1962 on Local Enterprises is no longer compatible with the current conditions. Regional Representative Council (DPD) has drafted and proposed the Draft Law (RUU), but it has not been realized until now. BUMD will not advance if the law underlying it, is not adapted to the current conditions. In addition, BUMD also does not have a legal basis on its management which, therefore, leads to obscurity of its orientation whether it is public service oriented or profit oriented.[4]

Unclear BUMD regulation resulted in the absence of legal certainty in the management of BUMD. This study aims at finding out the existence of BUMD in the national law of the Republic of Indonesia. This problem is important to be discussed because the existence of BUMD in national law is required for the creation of legal certainty in the management of BUMD in order to achieve the goal of BUMDestablishment.

\section{RESEARCH METHODOLOGY}

This research is a normative juridical research. The data of this research are secondary data composed of (a) primary legal materials in the form of laws and regulation, and (b) secondary legal materialsincluding books and journals. The data were collected using literature reviews and document analysis. The data were analyzed using theconceptual approach and the statue approach. The theory used in this research was the stakeholder theory of modern corporation considering that the management of BUMD is aimed at stakeholder's interests so that a regulation corresponding to the demand of market and globalization is required.

\section{RESULTS AND DISCUSSION}

\section{A. BUMD Capital and Local Finance}

BUMD is established by paying attention to the needs of the region and the feasibility of the business of BUMD that will be established. BUMD is established based on the Local Regulation whose capital comes from local equity participation, loans, grants, and such other capital sources as reserve capitalization, revaluation of assets and share premium. In accordance with Article 1 point 40 of the Local Government Law, a Local-Owned Enterpriseis a business entity whose capital is wholly or partially owned by the Local Government. In addition to local equity participation at the time of BUMD establishment, the Local Government can also make equity participation after the BUMD has been established through the addition of capital sourced from local finance in the form of money or property owned by the Region.

Local capital investment in BUMD makes the capital of BUMD become a part of the local finance. The scope of local finance is regulated in Article 2 of Government Regulation Number 58 of 2005 and Article 2 of Regulation of the Minister of Home Affairs Number 13 of 2006 as amended by Regulation of the Minister of Home Affairs Number 21 of 2011 stating that the scope of local finance includes: a. the rights of the region to collect local taxes and leviesand to ask for loans; $b$. the obligations of the region to administer local government affairs and to pay the third party's bills; c. local revenue; d. local expenditure; e. local properties managed either by the region itself or by other parties includingmoney, securities, accounts receivables, goods, and other rights which can be valued with money, including properties separated from the local enterprises; f. the properties of other parties controlled by the local government in the context of implementing the local government'stasks and/or the public interest .

\section{B. BUMD Management}

The management of each enterprise shall be conducted in accordance with the form of the enterprise. In this case, BUMD may take the form of a Local Public Company or a Local Private Company as follows:

1. Local Public Company is a BUMD whose capital is fully owned by one Region and is not divided into shares. The organs of localpubliccompanyare composed of the head of local government as the local representativeof capital owner, board of directors and supervisory boards.

2. A LocalPrivate Company is a BUMD in the form of a limited liability company whose capital is divided into shares which are wholly or at least $51 \%$ (fifty one percent) owned by one region. The organs of a LocalPrivate Company are subject to the provisions of the organs of a limited liability company as stipulated in Law Number 40 of 2007 on Limited Liability Company that include (a) General Meeting of Shareholders (GMS); (B) board of directors; and (c) board of commissioners.

Local Government Law does not further elaborate the duties and responsibilities of the BUMD owner, either of Local Public Company or of Local Private Company. The Capital Owner of a Local Public Company is the head of local government as the local representative, while the capital owner of a Local Private Company is the Shareholder. When adopting the capital owner's duties and responsibilities, the capital owner holds the highest authority in BUMD and holds any authority not submitted to other company organs. Article 62 Paragraph (2) of Law Number 40 of 2007 on Limited Liability Company states that the GMS is entitled to obtain all information related to the Company's interest from the Board 
of Directors and Commissioners. Therefore, the authority of the GMS is clearly unlikelyto be delegated to the other organs.

Besides, the Local Government Law also does not regulate the specific duties and responsibilities of BUMD directors, leading to uncertainty for the BUMD Directors to carry out their duties and responsibilities. The BUMD directors hold an important position in BUMD. In carrying out their functions, the directors are given authority and full responsibility to conduct their management strategies. [5] In a limited liability company, there are several stakeholders such as shareholders, employees, community, living environment and the limited liability company itself. Specifically for BUMD limited liability company, there are some local interests that must be protected, one of which is economic development and public benefit in the region. [6] More specifically, the BUMD limited liability company running a businesses in a certain sector must comply with regulations in such sector.The BUMD limited liability company runninga banking business, for example, must be subject to the regulations in the banking sector;similarly, the BUMD limited liability company runninga plantation business must be subject to the regulations in the plantation sector.

When adopting the duties and responsibilities of the board of directors in general, the BUMD Board of Directors is the organ that manages and represents the BUMD which means that the BUMD management must be implemented in accordance with the interests, purpose and objectives of the BUMD. The BUMD Board of Directors is the trustee and the agent of BUMD because they managethe properties of BUMD and act out for and on behalf of BUMD. The trust relationship between the board of directors and the BUMD creates a fiduciary duty. In this context, the board of directors has a duty of loyalty and good faith; as well asa duty of diligence and care to BUMD.

In its implementation, the BUMD board of directors has immunity rules or protection from any responsibility born due to the transactions or activities undertaken by them in accordance with the limits of authority and power given to them by noting that the activitieshave been done with great care and good faith (business judgment rule). Business Judgment Rule is not applicable if the board of directors does not meet the process and the required procedure, and does not do the activities solely for the benefit of the company and the stakeholders.

Besides, Business Judgment Rule is not applicable when the decisions are made with fraud, have conflict of interest, and contain gross negligence. In addition, Board of Directors is said to have violated the duties if there are ultra vires, i.e. taking an action outside the intentions and objectives of the BUMD, and Fraud on minority, i.e.taking an action against the law made by BUMD that generally harms the BUMD although approved by other majority shareholders. [7]

\section{BUMD MONITORING}

The absence of law that specifically regulates BUMD also makes BUMD monitoring spread over several laws and regulations. The Local Government Law states that the supervision of Local Public Company BUMD is conducted by the Supervisory Board, while Local Private Company BUMDis supervised by the Board of Commissioners. The Local Government Law does not explain the duties and responsibilities of either Supervisory Board or Board of Commissioners, thus creating uncertainty for BUMD Board of Directors to carry out their duties and responsibilities. Therefore, the duties and responsibilities of either Supervisory Board or Board of Commissioners refer to relevant general provisions. That the monitoring of Local Public Company BUMD is conducted by the Supervisory Board and that the monitoring of Local Private Company BUMD is conducted by the Board of Commissioners also refer to the duties of the Board of Commissioners pursuant to Law Number 40 of 2007 on Limited Liability Company. According to Article 1 point 6 of Lawon Limited Liability Company, the Board of Commissioners has the duty to conduct general and/or special monitoring in accordance with the articles of association and to advise the Board of Directors. Under such regulation, the monitoring conducted by the Supervisory Board is only intended tothe Local Public CompanyBUMD; however, in its practice, it is found that the Local Private Company BUMDis also monitoredby the Supervisory Board. This is certainly not in accordance with the Local Government Law.

In addition to the monitoringconducted by BUMD organs, the monitoringof BUMD is also conducted by agencies outside BUMD i.e.Finance and Development Supervisory Agency (BPKP) under Presidential Regulation Number 192 of 2014 on Finance and Development Supervisory Agency. BPKP is the Government's internal supervisory apparatus under the president conducting government affairs in supervising the state/local finance and national development. BPKP's supervision overBUMD because BUMDis established on the basis of local finance or obtains equity participation from regional finances. In addition to BPKP, the Supreme Audit Agency (BPK) also has the authority to supervise BUMD;nevertheless, in its practice, BPK never did it due to the limited number of human resources owned byBPK when compared with the number of BUMDs in Indonesia.

The monitoring of BUMD is also conducted on a sectoral basis.BUMD in the field of banking, for example,is monitored by the Financial Services Authority under Act Number 21 of 2011 on Financial Services Authorities, BUMD in the field of mining is monitored by the Ministry of Energy and Mineral Resources pursuant to Article 13 of Government Regulation Number 55 of 2010 on the Guidance and Supervision of Mineral and Coal Mining Business Management, BUMD in fishery field is supervised by the Ministry of Marine Affairs and Fisheries pursuant to Law Number 32 of 2014 on Marine.

The effectiveness of BUMD monitoring done by BUMD organs and agencies outside BUMD requires good will from stakeholders because every BUMD has particular 
characteristics for every business sector and every region, so the monitoring of BUMD must pay attention to such characteristics. [8]

\section{BUMD from Private Law and Public Law}

According to the World Bank, more and more countries are aligning the rules of modern governance to BUMN and BUMD as well as treating BUMN and BUMDas they didto other private companies. It aims at giving companies greater operational flexibility.[9] Indonesia has not aligned the rules related to BUMD which becomesthe barriers to realize the intentions and objectives of its establishment optimally due to the inconsistency of related legislations such as private or public BUMD financial status.

On the one hand, Article 1 of the Local Government Law states that BUMD is a business entity whose capital is partly or wholly owned by the Region. On the other hand, Article 2 of Government Regulation Number 58 of 2005 and Article 2 of Regulation of the Minister of Home Affairs Number 13 of 2006 as amended by Regulation of the Minister of Home Affairs Number 21 of 2011 state that the scope of local finance includes: a. the rights of the region to collect local taxes and levies and to ask for loans; $b$. the obligations of the region to administer local government affairs and to pay the third party's bills; c. local revenue; d. local expenditure; e. local properties managed either by the region itself or by other parties including money, securities, accounts receivable, goods, and other rights which can be valued with money, including properties separated from local enterprises; f. the properties of other parties controlled by the local government in the context of implementing the local government'stasks and/or the public interest .

The definition arising from the recognition onlocal finance in Article 1 of the Local Government Law seems to declare that the BUMD finance is not separated from the local finance. This is in contrast with Article 2 of Government Regulation Number 58 of 2005 and Article 2 of Regulation of the Minister of Home Affairs Number 13 of 2006 as amended by Regulation of the Minister of Home Affairs Number 21 Year 2011 stating that the BUMD finance is separated from the local finance.

The definition of local finance has obviously become a burden for BUMD to realizeits objectives. The management of BUMD can either gain profits according to its business objectives or get losses. On the one hand, the losses suffered by BUMD are the BUMD finance as a legal entity; on the other hand,there is a statement that BUMD financeis included in thelocal finance which is part of the national economy. Law Number 31 of 1999 in conjunction with Law Number 20 of 2001 stipulates that unlawful acts causing harm to the state finance or local finance constitute a criminal act of corruption that can be sentenced. The BUMD management resulting in losses of BUMD can be regarded to have caused financial losses to the local finance which is a part of the national economy such transactions as regular routinesof BUMDoperations. Therefore, the management of BUMD must be supported by a consistent legal system. The desired legal rules are those that do not contradict one another. If there is a conflict because this is not impossible to take place due to various interests of thecommunity, such legal principles as lex superior derogat legi inferior(higher lawset aside lower law), lex specialis derogat legi generalis (special law set aside general law), and lex posterior derogat legi priori (recent law set aside old law) will consistently apply.

By implementing the principle of civil law in terms of capital deposits in a legal entity, any property or wealth deposited into BUMD is a legal event that is always categorized into a transaction between the founder or shareholders with the BUMD itself. Article 3 Paragraph (1) of Law Number 40 of 2007 on Limited Liability Company stipulates that the shareholders of the company are not personally liable for the commitments made on behalf of the company and are not liable for the loss of the company exceeding the value of the shares they have taken.

The ownership of BUMD shares is not a proof of ownership of BUMD assets, but only limited to the participation of BUMD shareholders in depositing capital with all possible business risks it faces. Therefore, the Local Government as a shareholder in the Local Private Company BUMD does not have any ground to exclude itself from the enforcement of the principles of civil law concerning a limited liability company legal entity. Therefore, the wealth of Local Private Company is not a local finance. The same provision applies to Local Public Company BUMD, although intended for public benefits, its management shall be in accordance with company principles.

The purpose of separating legal entity (BUMD) from the state institution is to limit the responsibility of a legal entitiy (BUMD) in the event of business exposure from the business decisions it has undertaken, so it does not touch the local finance of other regions. Inconsistency in looking at the state's wealth in BUMD brings both positive and negative juridical consequences. On the one hand, it will give a warning anda threat of criminal prosecution when there is a mistake in the management of BUMDproperties. On the other hand, the Indonesian Civil Law system holds the principle that the owner is responsible for the consequences caused by the properties under his control, as well as the guarantee of achievement fulfillment (debt payments) covering the properties that have or will have existed. For example, if BUMD in the field of water management experiences pollution resulting in massive consumer poisoning, then strict liability claim can extend and reach up to other state's properties outside the BUMD.

From the perspective of the financial balance of BUMD, the BUMD finance is not a local finance. The financial statement and balance sheet of BUMD only show or only include the profit and loss of the company's activities, and the description of company's properties is not the activity of local income and expenditure budget. Therefore, the local revenue 
earned from BUMDis realized only in the form of dividends and taxes.

\section{E. Good Corporate Governance in BUMD Management}

In order to achieve the objective of its establishment,BUMD management must be done through a good corporate governance. Through the implementation of such good corporate governance, BUMD can make better decisions, mitigate abuse of authority, increase the stakeholder trust and increase the company profits. [10] BUMD management through a good corporate governance can be seen from some basic principles of Good Corporate Governance.According to National Committee of Governance Policy, a good corporate governance of every company [11] has the following basic principles:

1. Transparency,i.e. openness in carrying out the decision-making process and openness in conveying the relevant material information about the company. In this context, BUMD must provide timely, adequate, clear, accurate, and comparable information which is easily accessible by the stakeholders in accordance with their rights, such as the vision, mission, business goals and corporate strategy, financial condition, controlling shareholder, supervision and internal control system, system and implementation of Good Corporate Governance as well as its compliance level, and other important events that may affect the financial condition. In this case, the principle of openness does not reduce the obligation to comply with the company's confidentiality requirements in accordance with laws and regulations, job secrets, and personal rights. Such company policy must be written and proportionally communicated to the stakeholders.

2. Accountability,i.e. the clarity of functions, implementation and accountability of the organization in order to make the company management implemented effectively. Accountability is done by providing access to information in accordance with the principle of transparency and providing opportunities to the stakeholders in providing input for the interests of the company. In addition, the Company provides a fair and equitable treatment to the stakeholders in accordance with the benefits and contributions they made to the company. Accountability is also implemented to the company employees by providing equal opportunities and without discrimination since they arehiredand as long as they carry out their duties professionally.

3. Responsibility, i.e. conformity in the company management with the prevailing laws and regulations and sound corporate principles.

4. Independence, i.e.a condition where the company is managed professionally without conflict of interest and influence/pressure from any party that is not in accordance with prevailing laws and principles of healthy corporations. BUMD must define the details of the duties and responsibilities of each company's organ and all employees clearly corresponding to the vision, mission, corporate values, and corporate strategy whereby all the company organs and employees have the capability in accordance with theirduties and responsibilities, as well as their role in implementing a Good Corporate Governance. In addition, BUMD must ensure an effective internal control system in the management of BUMD, and the company organs and all the employees must adhere to the agreed business ethics and code of conduct.

5. Fairness, i.e. fairness and equality in fulfilling the rights of stakeholders arising under the prevailing laws and regulations. [12]

The biggest challenge in implementing the principles of a good corporate governance in BUMD is the independence of BUMD because its management is inseparable from the political appointment [13] between the interests of the Local Government as the local representative of BUMD owners together with its central role [14] and the interests of BUMD management based on the principles of a good corporate governance. Therefore, the purpose of BUMD management with the principle of a good corporate governance must have a clear goal.On the one hand, the local government is not a business actor but has a primary responsibility in developing and providing service to the community. On the other hand, the implementation of development requires a large amount of capital. Therefore, the existence of BUMD must be aimed at supporting the development and community service by not harming the local finance, yet by having to give benefits to the local finance. [15] BUMD is established as the completeness of Local Government in building the economy of the community in its region, where the BUMD is established.

1. Commercial/Profit (APBD).The purpose of BUMD establishment is purely a profit motive with the intention of increasing the Original Local Revenue from the dividend deposited into the LocalTreasury. The dividend earned from BUMD will then become the revenue of the local government that will increase the capability of Local Government Budget (APBD) to finance the region development. The success of BUMD performance is based on how much its ability is to contribute dividend to the APBD;

2. Public service improvement.The BUMD establishment is also intended to improve the services to the public. If the goal is to improve the services, then profit is not the motive of the company's operation. The approach of its financial performance assessment is done by looking at its ability to perform cost recovery with its level of efficiency and the quality of service;

3. Pioneering.The Local Government sometimes has to take the initiative to join a high-risk business that the private sector may not dare to join. This risk should be taken over by the Local Government because thebusiness or industry is actually very strategic. Thus, BUMD, whose establishment is intended to serve as pioneering, may suffer losses due to business risks so that the Local Government must provide additional capital to cover the losses incurred; 
4. Local economy prime mover. The company that is positioned as a local economy prime mover usually operates in the upstream industry, where its production is used by the downstream industry. Through the establishment of upstream industry, it is expected to become the locomotive of the downstream industry growth so that the acceleration of local economic growth will get faster. Upstream industries usually require substantial capital, sophisticated machinery and highly competent human resources;

5. Low economy advocates. BUMD can also be assigned to foster small entrepreneurs with a view to the equity, education and development of small and medium scale businesses to be able to climb a higher class. [16]

\section{CONCLUSIONS}

The Law on BUMD is required as a legal basis for the management of BUMD. The Law on BUMD as the basis for harmonization of BUMD related legislation uses the principle of lex superior derogat legi inferior (higher law set aside lower law), lex specialis derogat legi generalis (special law set aside general law), and lex posterior derogat legi priori (recent law set aside old law) so that BUMD can be managed with the principles of a good corporate governance for the interests of stakeholders by balancing the public benefits and profit. The Law on BUMD is expected to be the basic principle of a good corporate governance of BUMD management so that a good corporate governance is consistently and sustainably enforced.

\section{REFERENCES}

[1] Sondang P. Siagian, Administrasi Pembangunan: Konsep, Dimensi dan Strateginya, Penerbit Bumi Aksara, Jakarta, 2005, hlm. 77

[2] Friedmann W dalam Abrar. Hak Penguasaan Negara atas Pertambangan Berdasarkan UUD 1945. Disertasi, PPs Universitas Padjadjaran, Bandung. 1999, hlm 28.

[3] Christian Orchad Parangin-angin, Nasionalisme di Perusahaan Nasionalisasi: Menuju Profesionalisme Perusahaan BUMN Perkebunan, Jakarta, Bhuana Ilmu Populer, 2017.

[4] http://dpd.go.id/berita-bumd-masih-menggunakan- uu-lama, diakses pada tanggal 26 April 2017, pukul 1.54 WIB

[5] Hardijan Rusli, Perseroan Terbatas dan Aspek Hukumnya, Jakarta, Pustaka Sinar Harapan, 1997, hlm. 141.

[6] Sidargo Gautama, The Commercial Law of Indonesia, Bandung, Citra Aditya Bakti, 1998, hlm. 207-208.

[7] Gunawan Widjaya, 150 Pertanyaan Tentang Perseroan Terbatas, Jakarta, Forum Sahabat, 2008, hlm. 67-71

[8] Ambar Budhisulistyawati, Yudho Taruno Muryanto, Anjar Sri CN, "Strategi Pengelolaan Badan Usaha Milik Daerah (BUMD) Persero Untuk Mewujudkan Prinsip Tata Kelola Perusahaan Yang Baik", Jurnal Privat Law, Vol III No. 2, 215, hlm. 56-66

[9] World Bank Group, Corporate Governance of State Owned Enterprises, A Toolkit, Washington, 2014, hlm. 33

[10] Yudho Taruno Muryanto, "Model Pengelolaan Badan Usaha Milik Daerah (BUMD) Dalam Rangka Mewujudkan Good Corporate Governance", Jurnal Yustisia, Edisi 88, 2014, hlm. 127

[11] Miko Kamal, "Corporate Governance and State-Owned Enterprises: A Study of Indonesia's Code of Corporate Governance", Journal of International Commercial Law and Technology, Vol. 5 Issue 4, 2010, hlm. 206-224

[12] Keputusan Menteri BUMN No. KEP-117/M-MBU/2002
[13] Esther Wanjugu Gitundu, Sifunjo E. Kisaka, Symon Kibet Kiprop, Lawrence Kangogo Kibet, " The Effects of Ownership and Corporate Governance Reforms on Effeciency of Privatized Companies in Kenya", International Journal of Economics and Financial Issues, Vol. 6 Issues 1, 2016, hlm. 323-330.

[14] Dwi Budi Santosa, "Kebijakan Optimalisasi Peran Badan Usaha Milik Daerah (BUMD) Jawa Timur", Jurnal Aplikasi Manajemen, Vo. 9 No. 2, 2011, hal. 525

[15] Aminuddin IImar, Hukum Penanaman Modal di Indonesia, Keneana, Jakarta, 2004, hlm. L

[16] Farid Pradana MB, "Good Corporate Governance Dalam Perspektif Manajemen Strategik Badan Usaha Milik Daerah (Studi Deskriptif Tentang Good Corporate Governance Dalam Perspektif Manajemen Strategik Pasar Induk Puspa Agro)", Jurnal Kebijakan dan Manajemen Publik, Universitas Airlangga, hlm. 1-8 